\title{
LINKING EXOTIC SNAILS TO CARBON CYCLING IN KELLY WARM SPRINGS, Grand Teton National PARK
}

\author{
ERIN R. HOTCHKISS AND ROBERT O. HALL, JR. \\ DEPARTMENT OF ZOOLOGY AND PHYSIOLOGY $\downarrow$ UNIVERSITY OF WYOMING \\ LARAMIE
}

\section{$\downarrow$ ABSTRACT}

Biotic calcification has yet to be considered in most freshwater carbon budgets, despite previous calculations that suggest the importance of calcifying animals in altering inorganic carbon cycling. The freshwater snail, Melanoides tuberculata, has achieved a high abundance and a biomass of $34.2 \mathrm{~g} \mathrm{AFDM} \mathrm{m}^{-2}$ after invading Kelly Warm Springs in Grand Teton National Park approximately five years ago. This high biomass suggests that introduced populations of Melanoides may alter ecosystem processes. We measured Melanoides growth rates and biomass to calculate the production of biomass, shell mass, and $\mathrm{CO}_{2}$ for comparison with ecosystem carbon pools and fluxes.

Melanoides calcification in Kelly Warm Springs produced up to $10.4 \mathrm{mmol} \mathrm{CO}_{2} \mathrm{~m}^{-2}$ day $^{-1}$ during summer months. Despite extremely high primary production and respiration in Kelly Warm Springs ( $-379 \mathrm{mmol} \mathrm{CO}_{2} \mathrm{~m}^{-2} \mathrm{day}^{-1}$ and $445 \mathrm{mmol}$ $\mathrm{CO}_{2} \mathrm{~m}^{-2}$ day ${ }^{-1}$, respectively), $\mathrm{CO}_{2}$ produced from biotic calcification increased total $\mathrm{CO}_{2}$ production in Kelly Warm Springs from 65.9 to $76.3 \mathrm{mmol}$ $\mathrm{CO}_{2} \mathrm{~m}^{-2}$ day ${ }^{-1}$. This rate of $\mathrm{CO}_{2}$ production via biotic calcification is within the range of those previously calculated for freshwater systems and suggests the importance of considering the role of calcification in inorganic carbon budgets for areas dominated by calcifying organisms.
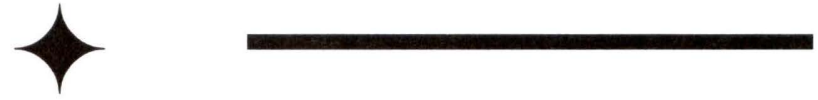
$\mathrm{CO}_{2}$ evasion from some aquatic ecosystems is an important source of $\mathrm{CO}_{2}$ that may be missing from many regional carbon budgets (Cole et al. 1994, Richey et al. 2002, Cole et al. 2007). Until recently, many estimates of global carbon sources and sinks did not include contributions from freshwater ecosystems. Many streams and rivers in the United States are supersaturated with $\mathrm{CO}_{2}$ (Jones et al. 2003), meaning that they are already sources of $\mathrm{CO}_{2}$. Further $\mathrm{CO}_{2}$ production through respiration or biotic calcification may increase the amount of $\mathrm{CO}_{2}$ released into the atmosphere. Biotic calcification may be an important aspect of stream, lake, and river outgassing of $\mathrm{CO}_{2}$ that should be considered when calculating contributions to the global carbon budget. Increases in $\mathrm{CO}_{2}$ concentrations, linked with heavy consumption of primary producers by consumers, can potentially lower the productivity status and may also raise local carbon emission budgets for invaded ecosystems (Cole et al. 2000, Duarte and Prairie 2005).

The freshwater snail, Melanoides tuberculata (Müller, 1774), has invaded warm aquatic habitats with unknown consequences. Melanoides has achieved high abundance and biomass in Kelly Warm Springs, Grand Teton National Park. This high biomass suggests that Melanoides has the potential to drastically change the elemental cycling, productivity, and community structure of invaded habitats (Chauvaud et al. 2003, Hall et al. 2003, Hall et al. 2006). While there is evidence that Melanoides can decrease the abundance of native macroinvertebrates (Giovanelli et al. 2005), the ecosystem-level consequences of Melanoides on carbon cycling is unknown. Introduced populations of Melanoides (as well as other exotic mollusks) may dramatically alter the $\mathrm{CO}_{2}$ production and emissions of invaded habitats through respiration and shell synthesis.

This paper links the calcification rates of an exotic snail population with ecosystem level fluxes and processes. In order to evaluate the impacts of Melanoides on carbon cycling in Kelly Warm Springs, we asked: 1) How much $\mathrm{CO}_{2}$ is released into Kelly Warm Springs through $\mathrm{CaCO}_{3}$ shell synthesis by Melanoides?, and 2) To what degree do snails alter inorganic carbon cycling relative to gross primary production and community respiration? To answer these questions, we measured growth rates, biomass and shell mass of Melanoides in Kelly Warm Springs to calculate rates of organic and inorganic carbon production, and translated shell growth rates into rates of $\mathrm{CO}_{2}$ production via calcification. We also compared these snail-driven rates with estimates of gross primary productivity, community respiration, concentrations of carbonate species, and net $\mathrm{CO}_{2}$ flux into the atmosphere. We predicted that including Melanoides calcification rates in the carbon budget would increase the total $\mathrm{CO}_{2}$ production in Kelly Warm Springs due to their high abundance and biomass.

\section{$\downarrow \quad$ MATERIALS AND METHODS}

\section{Study site and Melanoides life history}

Kelly Warm Springs is located in Grand Teton National Park (Wyoming, USA) at $43^{\circ} 38^{\prime}$ $21.8^{\prime \prime} \mathrm{N}, 110^{\circ} 37^{\prime} 01.9^{\prime \prime} \mathrm{W}$ (Figure 1) and originates from where the Gros Ventre River crosses a concealed Holocene or Pleistocene fault (Love and Love 1988). Acid neutralizing capacity and $\mathrm{pH}$ averaged 3.2 meq $\mathrm{L}^{-1}$ and 8.1 from June September 2006, including measurements taken every three hours during 24-hour sampling periods. The average width and depth of Kelly Warm Springs measured $9.9 \mathrm{~m}$ and $0.3 \mathrm{~m}$, respectively. Stream velocity was $7.4 \mathrm{~m} \mathrm{~min}^{-1}$ (standard deviation $=1.3$ ) and discharge was $5.7 \mathrm{~m}^{3} \mathrm{~min}^{-1}$ (standard deviation $=0.05$ ). Temperatures in Kelly Warm Springs ranged from $22.6-31.3^{\circ} \mathrm{C}($ mean $=$ $27.3{ }^{\circ} \mathrm{C}$ ) along a $500 \mathrm{~m}$ reach.

Because of the comfortable water temperature, Kelly Warm Springs is used heavily as a swimming and kayak training area for Jackson Hole residents and park visitors. The popularity of Kelly Warm Springs has resulted in numerous introductions and the successful establishment of exotic tropical fish and snails; likely through aquarium dumping. Five species of introduced fish have been documented in the USGS Nonindigenous Aquatic Species database: Xiphophorus helleri (green swordtail), Puntius tetrazona (tiger barb), Tilapia sp. (tilapia), Cichlasoma nigrofasciatum (convict cichlid) and Poecilia reticulata (guppy). All of the species except $P$. tetrazona are categorized as locally established populations (USGS 2005). In summer 2003, we observed Melanoides in Kelly Warm Springs, and while we do not know the exact date of introduction, Melanoides were absent from invertebrate samples collected in 2001 (R.O. Hall and E.R. Hotchkiss, unpublished data). 
Melanoides tuberculata (Gastropoda, Thiaridae) are likely native to eastern Asia but have established populations around the world through at least six different introductions since 1950 (Robinson 1999, Facon et al. 2003). Invasive populations of Melanoides are closely linked with the aquarium trade. They are limited to warm fresh and brackish waters with temperatures ranging from 14 to $31{ }^{\circ} \mathrm{C}$ (Dudgeon 1986, Duggan 2002). Melanoides burrow in substrate during the day and become more active at night (Figure 1).

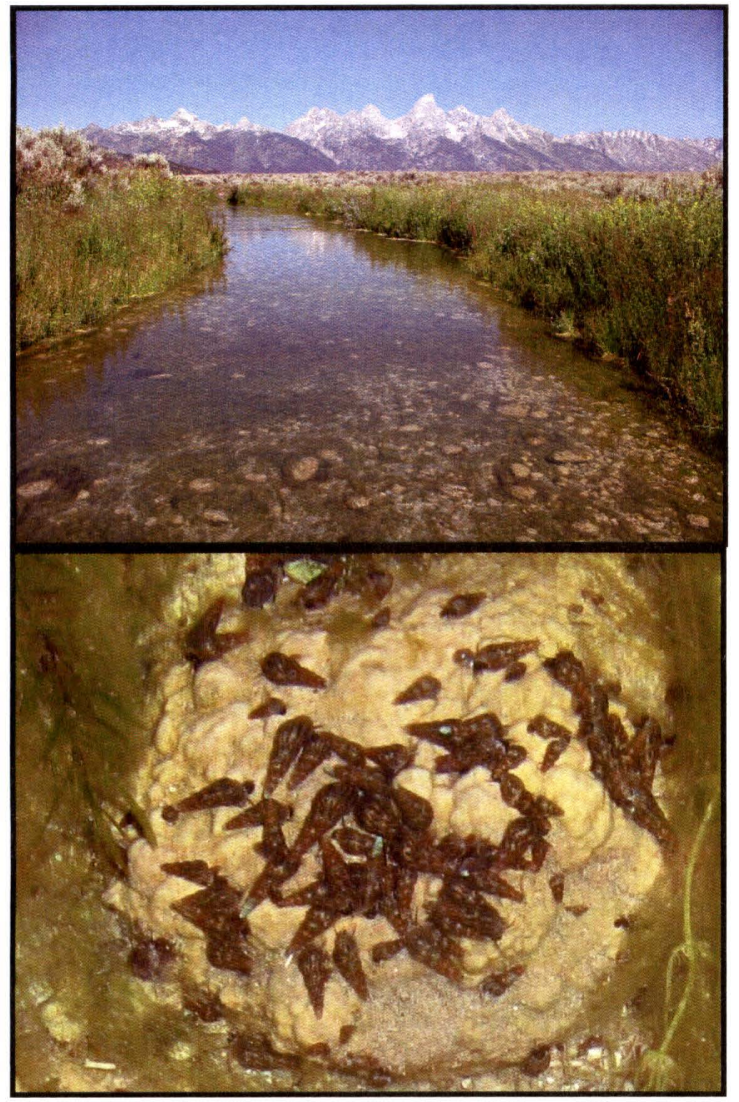

Figure 1. Kelly Warm Springs, Grand Teton National Park, Wyoming in top photograph (July 2006). Bottom photograph shows a close-up of Melanoides tuberculata while active at night (July 2007).

Individuals can grow up to $35 \mathrm{~mm}$ in length (although extremes of $80 \mathrm{~mm}$ have been reported), which is likely equivalent to 3 to 5 years in age (Dudgeon 1986, Duggan 2002, Rader et al. 2003). Melanoides are parthenogenetic and viviparous; embryos develop in the mother and young range from $1.0-4.0 \mathrm{~mm}$ in length when they are released from the brood pouch (Berry and Kadri, 1974, Subba Rao and Mitra 1982). A majority of populations sampled worldwide consist entirely of females (Jacob 1957, Dudgeon 1986), but Livshits and Fishelson (1983) reported up to $33 \%$ males in small, isolated populations in Israel. Melanoides establish in new environments quickly and can out-compete other invertebrates through facilitation (specifically Biomphalaria spp., the intermediate host of Schistosoma mansoni). Because of this, Melanoides have been intentionally introduced in some areas of Latin America and the Caribbean as biological control against schistosomiasis (Pointier and Giboda, 1999, Giovanelli et al. 2003).

\section{Melanoides production}

During June - September 2006, we sampled benthic macroinvertebrates along a $500 \mathrm{~m}$ reach of Kelly Warm Springs. We collected monthly samples from six random sites along the $500 \mathrm{~m}$ reach using a stovepipe sampler $15.2 \mathrm{~cm}$ in diameter and rinsed samples in the field with a 250- $\mu \mathrm{m}$ sieve (Hall et al. 2006). We sorted, counted and measured Melanoides and other macroinvertebrates using 1-mm and $250-\mu \mathrm{m}$ sieves to separate all benthic invertebrates and digital calipers to measure shell lengths the nearest tenth of a millimeter. Each stovepipe sample was subsampled following Hall et al. (2006). All macroinvertebrates were preserved in $95 \%$ ethanol. We also measured and counted Melanoides collected in summer 2004 for comparison with summer 2006 population estimates.

We developed a length/mass regression for both biomass and shell mass using dried, unpreserved Melanoides collected in June 2006 to calculate biomass estimates for the population in Kelly Warm Springs. We dried, weighed, ashed (at $500{ }^{\circ} \mathrm{C}$ for four hours) and re-weighed 157 individuals from a range of size classes. Predictive equations for 27 size classes were derived using SAS PROC REG (SAS Institute 2002-2003). We calculated size-specific biomass and shell mass for Melanoides collected in 2004 (4 stovepipe samples) and monthly during summer 2006 using the relationship between shell length, shell mass, and biomass. In order to understand the severity of this invasion in terms of organic carbon cycling, we also quantified the percent of macroinvertebrate biomass that consisted of Melanoides in comparison to native species.

We measured in situ growth rates of Melanoides during July and August 2006. We placed $4-8$ individuals from similar size classes (controlled for biomass to avoid over-crowding) 
with a small rock and attached algae in $56 \mathrm{x} 43 \mathrm{~mm}$ growth cages with $244-\mu \mathrm{m}$ nylon mesh (Toby TeaBoy Ltd., Hall et al. 2006). We removed any other macroinvertebrates that were embedded in the algae. Size classes were determined by shell length and binned in $0.5 \mathrm{~mm}$ increments. We secured the growth cages in Kelly Warm Springs for three week incubations (Hall et al. 2006). We immediately preserved individuals from each growth cage after collection at the end of the three week period. We re-measured shell lengths to calculate mass, from which we estimated growth rates as

Growth rate $\left(\right.$ day $\left.^{-1}\right)=\frac{\ln \left(\text { mass }_{t}\right)-\ln \left(\text { mass }_{0}\right)}{t}$,

where mass $_{0}$ is the initial mass of the individuals in the growth cage, mass, is the mass of the individuals at the end of the growth period, and $t$ is the length of the growth period (in days). This equation was used for both shell mass and biomass calculations.

Because growth rates highly depend on temperature, we also measured the range of temperatures throughout the entire growth period using temperature dataloggers secured to the bottom of Kelly Warm Springs at our $0 \mathrm{~m}$ and 500 $\mathrm{m}$ sites (HOBO Water Temp Pro v2, Onset Computer Corporation). We calculated sizespecific growth rates for the Kelly Warm Springs population using SAS PROC REG to find the best predictive regression (SAS Institute 2002-2003).

After measuring size-specific growth rates and biomass for Melanoides in Kelly Warm Springs, we calculated secondary production for the summer season as

Somatic Secondary Production $=\sum_{i=1}^{n} g_{i} B_{i}$,

where $\mathrm{g}_{i}$ is instantaneous growth $\left(\right.$ day $\left.^{-1}\right)$ and $\mathrm{B}_{i}$ is biomass $\left(\mathrm{g} \mathrm{m}^{-2}\right)$ for the $i$ th size class of snails (Benke 1984).

We also incorporated fecundity for Melanoides to estimate the relative contribution of reproduction versus growth to total biomass production in Kelly Warm Springs. All of our fecundity calculations were based on the assumption that juvenile snails were $1.5 \mathrm{~mm}$ in length at the time of their emergence from the brood pouch. We measured the dry and ash-free dry mass of the smallest Melanoides collected from Kelly Warm Springs for calculations of biomass and shell mass production. Reproduction in native and invasive regions occurs continuously and often peaks in response to environmental variables (Berry and Kadri 1974, Dudgeon 1986, Pointer $e t$ al. 1992). We chose a conservative reproduction rate of 182 year $^{-1}$ for all individuals between 12.0 and $25.0 \mathrm{~mm}$ in length (Berry and Kadri 1974, Subba Rao and Mitra 1982).

\section{Carbon cycling in Kelly Warm Springs}

We measured community respiration and gross primary production $\left(\mathrm{g} \mathrm{O}_{2} \mathrm{~m}^{-2}\right.$ day $\left.^{-1}\right)$ using the two station open channel method for oxygen (Odum 1956). We placed two Hydrolab MiniSondes in Kelly Warm Springs at each end of a $500 \mathrm{~m}$ reach for three day cycles during July and August 2006 to measure changes in dissolved oxygen (DO) concentrations. Using measurements of width, depth, travel time, and $k_{\mathrm{O}_{2}}$, we calculated instant metabolism throughout seven different 24hour cycles (Hall et al. 2007) as

Instant Metabolism $\left(\mathrm{g} \mathrm{O}_{2} \mathrm{~m}^{-2} \mathrm{~min}^{-1}\right)=z\left[\frac{\left(C_{t}-C_{0}\right)}{t}-k D O_{D e f}\right]$, where $C_{t}$ and $C_{0}$ are the dissolved oxygen concentrations at upstream and downstream sites ( $\mathrm{g}$ $\left.\mathrm{O}_{2} \mathrm{~m}^{-2}\right), \mathrm{t}$ is water travel time between sondes (min), $k$ is the reaeration coefficient for $\mathrm{O}_{2}\left(\mathrm{~min}^{-1}\right)$, $D O_{D e f}$ is the average of the dissolved oxygen deficit measured upstream and downstream $\left(\mathrm{g} \mathrm{O}_{2}\right.$ $\left.\mathrm{m}^{-3}\right)$, and $z$ is stream depth (m).

We used these instant metabolism measurements to calculate GPP (gross primary production) as

$$
\operatorname{GPP}\left(\mathrm{g} \mathrm{O}_{2} \mathrm{~m}^{-2} \text { day }^{-1}\right)=\left[\mathrm{I}^{*} \sum\left(\mathrm{M}-\mathrm{M}_{\mathrm{PM}}\right)\right] \text {, }
$$

where $\mathbf{I}$ is the measurement interval (min), $\mathbf{M}$ is instant metabolism, and $\mathrm{M}_{\mathrm{PM}}$ is average night metabolism (the mean of instant metabolism rates during the nighttime). We calculated CR (community respiration) as $\mathrm{CR}\left(\mathrm{g} \mathrm{O}_{2} \mathrm{~m}^{-2}\right.$ day $\left.^{-1}\right)=\left[\mathrm{M}_{\mathrm{PM}} * 1440\right]$, where 1440 is total minutes day ${ }^{-1}$. We used the common assumption that $\mathrm{CR}$ during the daytime was equal to CR measured at night. We did not adjust for groundwater inputs because conservative tracer $(\mathrm{NaCl})$ concentrations did not decline along our study reach. The one station open channel method was used during two periods in July. We converted $\mathrm{O}_{2}$ to $\mathrm{CO}_{2}$ using a photosynthetic quotient of 1.2 (Raine 1983). 
In order to accurately measure the amount of air-water gas exchange with respect to $\mathrm{O}_{2}$ and $\mathrm{CO}_{2}$ fluxes, we used tracer additions of sulfur hexafluoride $\left(\mathrm{SF}_{6}\right)$, a biologically inert gas. We also added a conservative tracer, $\mathrm{NaCl}$, to calculate travel time and any dilution from potential groundwater inputs along the reach (Wanninkhof $e t$ al. 1990). $\mathrm{SF}_{6}$ is not naturally present in aquatic ecosystems and evades at a rate that can be used to calculate $\mathrm{O}_{2}$ and $\mathrm{CO}_{2}$ evasion (Wanninkhof et al. 1990, Cole and Caraco 1998). We collected triplicate dissolved gas samples at 5 stations along an $800 \mathrm{~m}$ reach downstream from the release site and measured the decline in $\mathrm{SF}_{6}$ concentrations using a gas chromatograph with an electron capture detector (Shimadzu Gas Chromatograph 14A). $k_{\mathrm{SF} 6}$, the piston velocity $\left(\mathrm{m} \mathrm{min}^{-1}\right)$, was calculated from the three separate $\mathrm{SF}_{6}$ releases and the decline in $\mathrm{SF}_{6}$. We used our average $k_{\mathrm{SF} 6}$ to calculate $k_{\mathrm{O} 2}$ and $k_{\mathrm{CO} 2}$ using the ratios of gas exchange coefficients and Schmidt numbers for the gas of interest (Wanninkhof 1992, Cole and Caraco 1998).

$$
\frac{k_{\text {gas } 1}}{k_{\text {gas } 2}}=\left[\frac{S c_{\text {gas } 1}}{S c_{\text {gas } 2}}\right]^{n},
$$

where $k$ is the gas exchange coefficient, $\operatorname{gas}_{1}$ is $\mathrm{SF}_{6}$, gas $_{2}$ is $\mathrm{CO}_{2}$ or $\mathrm{O}_{2}, \mathrm{Sc}$ is the Schmidt number, and $n$ depends on processes dominating diffusion (Wanninkhof 1992, Cole and Caraco 1998). We assumed $n=1$ (Portielje and Lijklema 1995, Wanninkhof and Knox 1996).

We collected data on several water chemistry and physical parameters on a weekly basis and during diel sampling throughout summer 2006 at upstream $(0 \mathrm{~m})$ and downstream $(500 \mathrm{~m})$ sites along our reach. These data inlcuded temperature, acid neutralizing capacity (ANC) calculated by titration (Wetzel and Likens 2000), pH (Orion 3-star portable pH meter with a ROSS Ultra ${ }^{\circledR} \mathrm{pH}$ Electrode, Thermo Scientific), conductivity and dissolved oxygen (Hydrolab MiniSondes, Hach Environmental). We collected duplicate $60 \mathrm{~mL}$ water samples from our upstream and downstream sites that were filtered, frozen, and later analyzed for concentrations of common cations and anions (Dionex ICS-2000 Ion Chromatography System with AS40 Automated Sampler and Perkin Elmer model 372 Atomic Absorption Spectrophotometer). We measured stream depth ( $\mathrm{z}$ ) and width (w) several times throughout the summer. We also measured stream velocity (V) and discharge (Q).
Using $\mathrm{pH}$, temperature and acid neutralizing capacity, we calculated dissociation constants for carbonic acid, concentrations of carbonate species, and total dissolved inorganic carbon. Carbonic acid dissociation constants (pK1 and $\mathrm{pK} 2$ ) were calculated using temperature adjustments from Cai and Wang (1998). We calculated the concentrations of different carbonate species using measurements of carbonate acid neutralizing capacity, $\mathrm{pH}$, and carbonic acid dissociation constants, following Millero (1979).

$$
\begin{aligned}
& {\left[\mathrm{H}_{2} \mathrm{CO}_{3}^{*}\right]=\mathrm{H}_{2} \mathrm{CO}_{3}+\mathrm{CO}_{2}=\frac{\left(\frac{\mathrm{A}_{\mathrm{C}} a_{\mathrm{H}}}{\mathrm{K} 1}\right)}{\left(1+\frac{2 \mathrm{~K} 2}{a_{\mathrm{H}}}\right)},} \\
& {\left[\mathrm{HCO}_{3}^{-}\right]=\frac{\mathrm{A}_{\mathrm{C}}}{1+\frac{2 \mathrm{~K} 2}{a_{\mathrm{H}}}},} \\
& {\left[\mathrm{CO}_{3}^{2-}\right]=\frac{\mathrm{A}_{\mathrm{C}} \mathrm{K} 2}{a_{\mathrm{H}}+2 \mathrm{~K} 2},}
\end{aligned}
$$

where [] represents the effective concentration in mmol m$~ m^{-3}, A_{C}$ is carbonate acid neutralizing capacity $\left(\mathrm{mmol} \mathrm{m}^{-3}\right)$ and $a_{\mathrm{H}}$ is the activity of $\mathrm{H}^{+}$. Total carbonate is the sum of $\left[\mathrm{H}_{2} \mathrm{CO}_{3}^{*}\right],\left[\mathrm{HCO}_{3}^{-}\right]$ and $\left[\mathrm{CO}_{3}^{2-}\right]$. We calculated partial pressure of $\mathrm{CO}_{2}$ (in atm),

$p \mathrm{CO}_{2}=\frac{\left\lfloor\mathrm{H}_{2} \mathrm{CO}_{3}^{*}\right\rfloor}{\mathrm{K}_{\mathrm{H}}}$,

using our indirect measurements of $\left[\mathrm{H}_{2} \mathrm{CO}_{3}^{*}\right]$ and Henry's constant for $\mathrm{CO}_{2}\left(\mathrm{~K}_{\mathrm{H}}, \mathrm{mol} \mathrm{m}^{-3} \mathrm{~atm}^{-1}\right)$ corrected for temperature and elevation (Langmuir 1997).

Our measurements of $\mathrm{CO}_{2}$ fluxes from Kelly Warm Springs were calculated by multiplying the $\mathrm{CO}_{2}$ deficit by the site-specific piston velocity for $\mathrm{CO}_{2}$.

$\mathrm{CO}_{2}$ Flux $\left(\mathrm{mmol} \mathrm{m}^{-2} \min ^{-1}\right)=\alpha k\left(\left(p \mathrm{CO}_{2} K_{H}\right)-\left[\mathrm{CO}_{2}\right]_{s a t}\right)$, where $\alpha$ is the chemical enhancement factor, $k$ is the piston velocity for $\mathrm{CO}_{2}\left(\mathrm{~m} \mathrm{~min}^{-1}\right), p \mathrm{CO}_{2}$ is the partial pressure of $\mathrm{CO}_{2}\left(\mathrm{mmol} \mathrm{CO}_{2} \mathrm{~m}^{-3}\right), K_{H}$ is the Henry's constant for $\mathrm{CO}_{2}\left(\mathrm{~mol} \mathrm{~m} \mathrm{matm}^{-1}\right)$, and $\left[\mathrm{CO}_{2}\right]_{\text {sat }}$ is the concentration of $\mathrm{CO}_{2}(\mathrm{mmol}$ $\mathrm{CO}_{2} \mathrm{~m}^{-3}$ ) at saturation (Cole and Caraco 1998). We adjusted $K_{H}$ for changes in temperature and elevation when we calculated $\mathrm{CO}_{2}$ saturation (Langmuir 1997). We used an average of current atmospheric levels of $\mathrm{CO}_{2}(380 \mu \mathrm{atm})$ for measurements of saturation (Tans 2007). 


\section{Contributions of Melanoides to carbon cycling}

After calculating $p \mathrm{CO}_{2}, \mathrm{CR}$, and the rate of air-water gas exchange in Kelly Warm Springs, we measured the rate of $\mathrm{CO}_{2}$ flux into the atmosphere and the extent to which Melanoides were responsible for making Kelly Warm Springs a local source of $\mathrm{CO}_{2}$. Using growth rates in combination with the $\mathrm{CaCO}_{3}$ content of varying shell sizes, we calculated the amount of $\mathrm{CaCO}_{3}$ produced by Melanoides and, consequently, the $\mathrm{CO}_{2}$ emitted through shell synthesis into Kelly Warm Springs during the summer months (Chauvaud et al. 2003).

We calculated the ratio $(\Psi)$ of released $\mathrm{CO}_{2}$ to fixed $\mathrm{CaCO}_{3}$ using adjustments for temperature and salinity by Frankignoulle $e t$ al. (1994). Approximately 0.6 moles of $\mathrm{CO}_{2}$ are released for every mole of $\mathrm{CaCO}_{3}$ precipitated in sea water and the ratio in freshwater is nearly 1.0, but $\Psi$ lowers with increasing temperature (Ware $e t$ al. 1991). Using a temperature- and salinityadjusted $\Psi(0.85)$ for Kelly Warm Springs, we converted calcification rates to $\mathrm{CO}_{2}$ production by Melanoides.

\section{$\downarrow$ RESULTS}

\section{Melanoides production}

The density of Melanoides in Kelly Warm Springs was 24,000 individuals $\mathrm{m}^{-2}$ (standard deviation $=13,000$ ) in summer 2006. The biomass of Melanoides in 2004 was $17.8 \mathrm{~g} \mathrm{AFDM} \mathrm{m}^{-2}$ (standard deviation $=12.9)$, with a density of $17,000 \mathrm{~m}^{-2}$ (standard deviation $=7,000$ ). The relationship between shell length and biomass can be described using the equation: [Biomass $(\mathrm{g}$ AFDM m $\left.\left.{ }^{-2}\right)\right]=0.0021[\text { Shell Length }]^{3.1153}(\mathrm{n}=27$, $\left.\mathrm{r}^{2}=0.96, \mathrm{p}<0.0001\right)$. Melanoides biomass was $34.2 \mathrm{~g} \mathrm{AFDM} \mathrm{m}^{-2}$ (standard deviation $=18.2$ ) in 2006. The relationship between shell length and shell mass can be described using the equation: [Shell mass $\left.\left(\mathrm{g} \mathrm{CaCO}_{3} \mathrm{~m}^{-2}\right)\right]=0.0223$ [Shell Length] ${ }^{2.9664}\left(n=27, r^{2}=0.99, p<0.0001\right)$. Shell lengths ranged from 1.4 to $33.9 \mathrm{~mm}$ (Figure 2).

Melanoides persisted at high densities 1.5 $\mathrm{km}$ downstream of the spring pool and at low densities along $0.5 \mathrm{~km}$ of a lower reach before Kelly Warm Springs merged with Ditch Creek. Total macroinvertebrate biomass in Kelly Warm Springs was $39.1 \mathrm{~g} \mathrm{AFDM} \mathrm{m}^{-2}$, including $4.9 \mathrm{~g}$
AFDM m ${ }^{-2}$ of native mollusks, arthropods, and annelids (standard deviation $=2.65$ ). Melanoides made up $87 \%$ of the total invertebrate biomass during summer 2006.

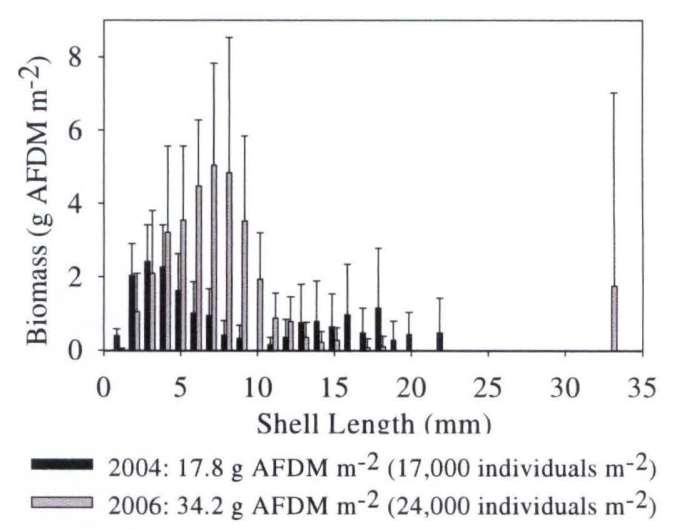

Figure 2. Frequency of biomass represented by each Melanoides size class in Kelly Warm Springs during summer 2004 and summer 2006. Error bars represent standard deviations.

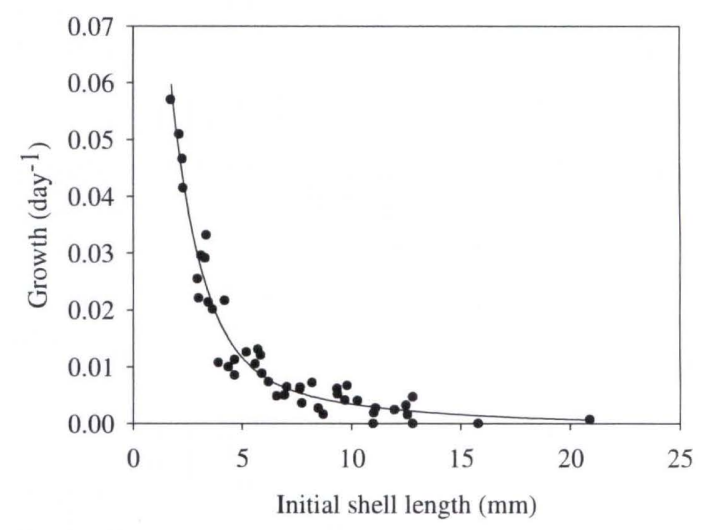

Figure 3. Size-specific growth rates for Melanoides in Kelly Warm Springs measured in situ from June September 2006. Growth rates are best predicted using the following equation: [growth rate $\left(\right.$ day $\left.^{-1}\right)$ ] $=0.0142 \mathrm{e}^{-}$ 0.1454 [shell length] $+0.1686 \mathrm{e}^{-0.7165[\text { shell length] }}\left(\mathrm{n}=46, \mathrm{r}^{2}=\right.$ $0.9507, \mathrm{p}<0.0001)$.

Growth rates were measured for Kelly Warm Springs Melanoides ranging from 1.5 to 13 $\mathrm{mm}$ in length. Growth rates were best predicted using the following equation: [growth rate $\left(\right.$ day $\left.^{-1}\right)$ ] $=0.0142 \mathrm{e}^{-0.1454 \text { [shell length] }}+0.1686 \mathrm{e}^{-0.7165 \text { [shell length] }}$ $\left(\mathrm{n}=46, \mathrm{r}^{2}=0.95, \mathrm{p}<0.0001\right)$. Because we did not measure individuals with an initial length less than $1.5 \mathrm{~mm}$ in our growth chambers, we assumed that they have the same growth rates as snails in the $1.5 \mathrm{~mm}$ size class, even though the growth rate of smaller snails is likely higher. By weighting size- 
specific growth rates with the relative abundance of each size class, we calculated an average growth rate of $0.02\left(\right.$ day $\left.^{-1}\right)$. We also assumed that individuals with an initial length greater than 13 $\mathrm{mm}$ had a growth rate of zero $\left(\right.$ day $\left.^{-1}\right)$. These large snails have a low abundance and we were unable to measure significant growth during our three week incubations (Figure 3).

Secondary production of Melanoides biomass in Kelly Warm Springs was 0.31 g AFDM $\mathrm{m}^{-2}$ day $^{-1}$ in 2006, with a P:B (production:biomass) of 3.3 year $^{-1}$ (without accounting for fecundity or potential seasonal changes in growth). The density of fecund individuals was $370 \mathrm{~m}^{-2}$ during summer 2006, yielding an estimated annual production of 67,000 young $\mathrm{m}^{-2}$ year $^{-1}$ and a daily production rate of $0.07 \mathrm{~g}$ AFDM (of young) $\mathrm{m}^{-2} \mathrm{day}^{-1}$. Combining production from the growth of the current population and the predicted fecundity of individuals 12.0 to $25.0 \mathrm{~mm}$ in length, Melanoides produced $0.4 \mathrm{~g} \mathrm{AFDM} \mathrm{m}^{-2} \mathrm{day}^{-1}$ and had a P:B of 4.1 year $^{-1}$ during summer 2006. Melanoides in Kelly Warm Springs produced 12.2 moles $\mathrm{CaCO}_{3}$ $\mathrm{m}^{-2}$ day $^{-1}$ through biotic calcification.

\section{Carbon cycling in Kelly Warm Springs}

The differences in CR and GPP between one and two station calculations were similar to the ranges measured between various dates during summer 2006. After comparing GPP and CR calculated using both the two station and the one station approach for the dates when we deployed two MiniSondes, we included our one station calculations from the end of July in our overall estimates of metabolism for Kelly Warm Springs. One and two station CR measurements differed by an average of $6.4 \%(\mathrm{n}=3$, standard deviation $=$ 6.8 ), while the average difference between one and two station GPP measurements was 9.6\% $(\mathrm{n}=5$, standard deviation $=5.5$ ).

Our releases of $\mathrm{SF}_{6}$ yielded a $\mathrm{k}_{\mathrm{SF} 6}$ value of $0.00155 \mathrm{~m}^{-1}(95 \%$ confidence interval for all three releases $\left.=5.66 \times 10^{-5}\right)$ and $\mathrm{a}_{600}$ value of 0.00136 . Gross primary productivity (GPP) and community respiration (CR) measurements over 14 days in July and August averaged $-379 \mathrm{mmol} \mathrm{CO}_{2} \mathrm{~m}^{-2}$ day $^{-1}$ (standard deviation $\left.=131\right)$ and $445 \mathrm{mmol}$ $\mathrm{CO}_{2} \mathrm{~m}^{-2}$ day ${ }^{-1}$ (standard deviation $=37.5$ ). Net ecosystem production (NEP) was $65.9 \mathrm{mmol} \mathrm{\textrm {CO } _ { 2 }}$ $\mathrm{m}^{-2}$ day $^{-1}$ (standard deviation $=128.9$ ). Despite a much higher GPP from 21-22 July in comparison to our other measurements (the measurements responsible for the high standard deviation), we do not believe these calculations are due to measurement error and included these data in our metabolism calculations for Kelly Warm Springs.

Kelly Warm Springs was consistently super-saturated with $\mathrm{CO}_{2}$ (with respect to current atmospheric levels of $380 \mathrm{ppm}) . \quad \mathrm{CO}_{2}$ partial pressure values ranged from 476.0 to $5421.5 \mu \mathrm{atm}$, with a mean of $2725.8 \mu \mathrm{atm}$ over 24 -hour cycles. $\mathrm{CO}_{2}$ evasion rates ranged from 0.0015 to 0.0556 $\mathrm{mmol} \mathrm{CO} \mathrm{m}^{-2} \mathrm{~min}^{-1}$, with higher fluxes during late evening and early morning and lower fluxes in the afternoon (Figure 4). Kelly Warm Springs contributed to an average flux of $37.2 \mathrm{mmol} \mathrm{CO}_{2}$ $\mathrm{m}^{-2}$ day $^{-1}($ standard deviation $=5.6)$.

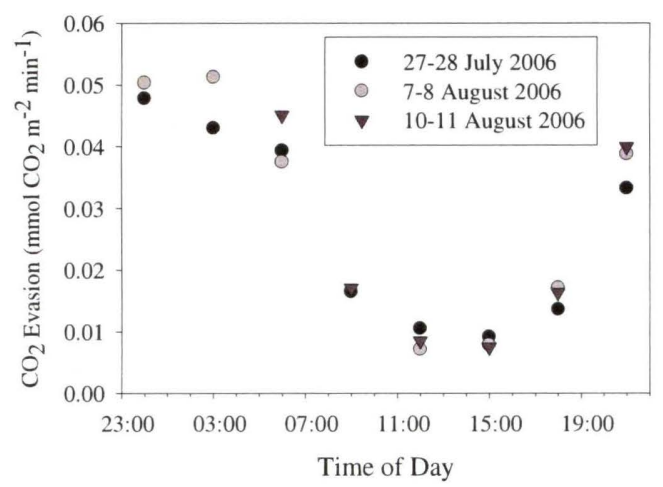

Figure 4. Net $\mathrm{CO}_{2}$ evasion over 3 different 24-hour periods in July and August 2006. The average $\mathrm{CO}_{2}$ flux from Kelly Warm Springs was $37.2 \mathrm{mmol} \mathrm{CO}_{2} \mathrm{~m}^{-2}$ day ${ }^{-1}$.

\section{Contributions of Melanoides to carbon cycling}

Using our direct measurements of Melanoides population density, growth rates and size frequency distributions, shell mass in Kelly Warm Springs was 1.9 moles $\mathrm{CaCO}_{3} \mathrm{~m}^{-2}$ and calcification rates averaged $12.2 \mathrm{mmol} \mathrm{CaCO}_{3} \mathrm{~m}^{-2}$ day $^{-1}$. During summer months, we estimated that biotic calcification by Melanoides contributed 10.4 $\mathrm{mmol} \mathrm{CO}_{2} \mathrm{~m}^{-2}$ day $^{-1}$ to the water column inorganic carbon pool. We assumed that $\mathrm{CO}_{2}$ produced as a byproduct of calcification was constant throughout day and night.

Compared to the daily swings of $\mathrm{CO}_{2}$ production and consumption in Kelly Warm Springs, calcification produced a relatively small amount of $\mathrm{CO}_{2}$ (Figure 5). However, this $\mathrm{CO}_{2}$ released from biotic calcification increased total $\mathrm{CO}_{2}$ production estimates for Kelly Warm Springs. Including calcification in the inorganic carbon budget for Kelly Warm Springs would increase net 
ecosystem production of $\mathrm{CO}_{2}$ from $65.9 \mathrm{mmol} \mathrm{CO}_{2}$ $\mathrm{m}^{-2}$ day $^{-1}$ to $76.3 \mathrm{mmol} \mathrm{CO}_{2} \mathrm{~m}^{-2}$ day $^{-1}$. Because the bicarbonate system in streams is dominated by $\mathrm{HCO}_{3}^{-}$, a large proportion of the $\mathrm{CO}_{2}$ produced via biological processes was transformed to $\mathrm{HCO}_{3}^{-}$. Relatively little $\mathrm{CO}_{2}$ was lost due to diffusion and reaeration (only $37.2 \mathrm{mmol} \mathrm{CO}_{2} \mathrm{~m}^{-2}$ day $^{-1}$, including losses from high- $\mathrm{CO}_{2}$ groundwater inputs upstream), despite Kelly Warm Springs being a net source of $\mathrm{CO}_{2}$ to the atmosphere (Figures $4 \& 6$ ).

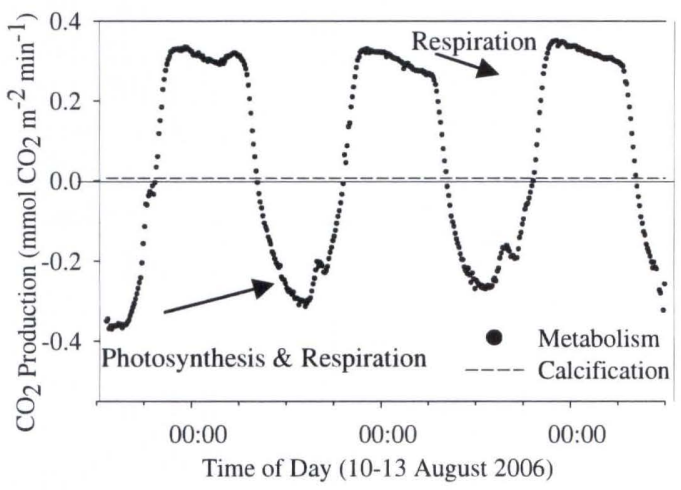

Figure 5. Comparison of $\mathrm{CO}_{2}$ production by stream metabolism versus calcification.

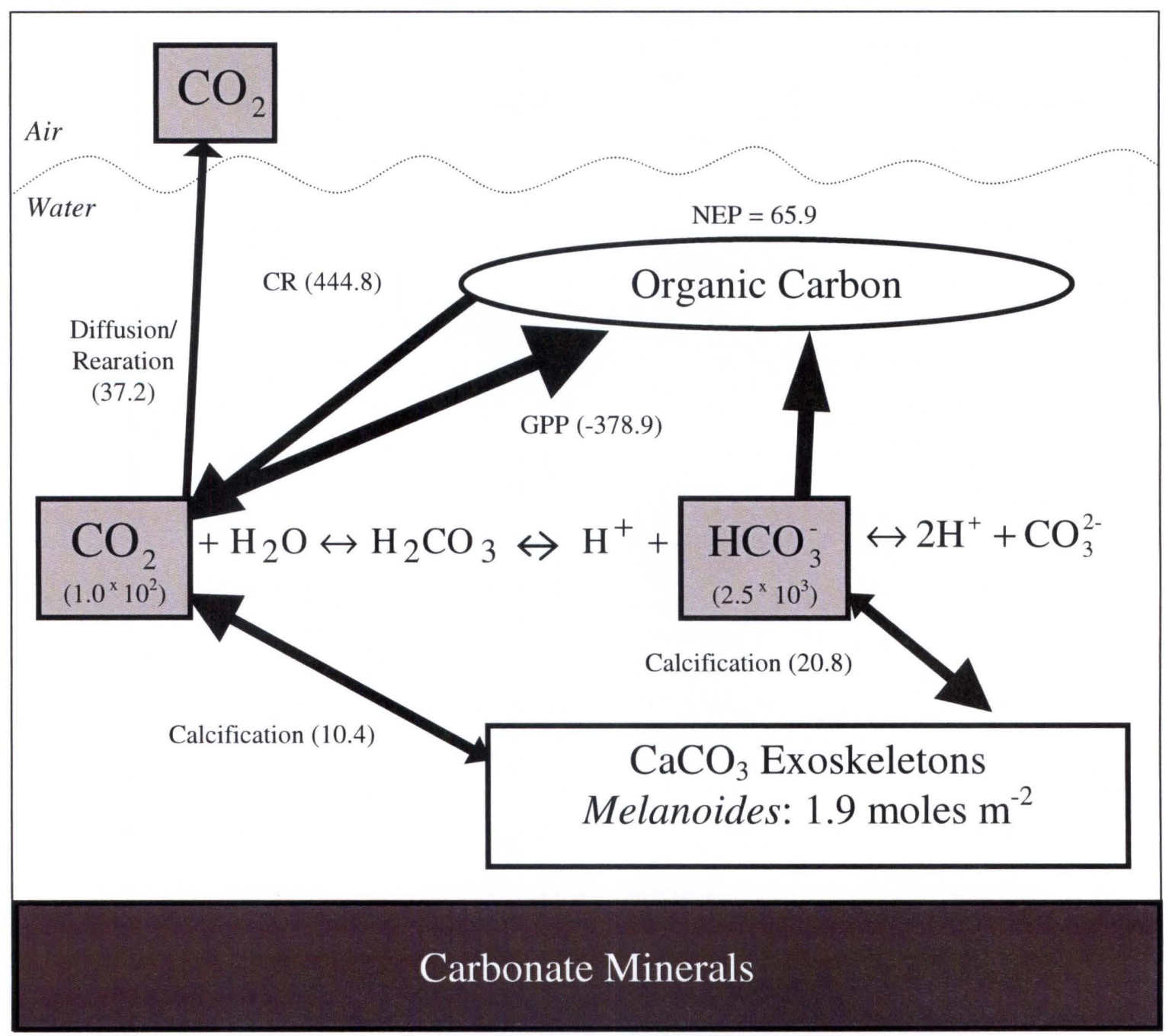

Figure 6. Carbonate pools and fluxes within and from Kelly Warm Springs, Wyoming. Arrows represent fluxes (mmol of $\mathrm{CO}_{2} \mathrm{~m}^{-2}$ day ${ }^{-1}$ ) and represent the relative contributions of each process to $\mathrm{CO}_{2}$ production. Boxes are standing stock. Note that primary production by biota in the organic carbon pool can take up $\mathrm{CO}_{2}$ or $\mathrm{HCO}_{3}{ }^{-}$, depending on the species. We did not measure dissolution of shells or carbonate minerals on the benthos for this specific study and assumed they were at steady state. 


\section{$\downarrow \quad$ DISCUSSION}

\section{Melanoides production}

Warm temperatures and high primary production in Kelly Warm Springs have likely facilitated one of the highest densities reported for Melanoides in the literature to date. Biomass production and shell calcification rates for Melanoides individuals were slower than rates published for other invasive snail species, but were important in terms of total invertebrate biomass due to the high density of Melanoides established in Kelly Warm Springs.

Melanoides tend to grow slowly and have lower fecundity compared to other successful invasive freshwater snails (Facon et al. 2006) Therefore, it is no surprise that the Melanoides annual P:B of 4.1 was lower than 9 and 12 year $^{-1}$ calculated for the invasive New Zealand mud snails in the greater Yellowstone area (Hall et al. 2006). Our calculations of annual P:B for the measured ranges of Melanoides fecundity (4.1 to 4.9 year $^{-1}$ ) are on either end of the reported values of 4.4 in Lake Kariba, Zimbabwe (Kiibus and Kautsky 1996) and 4.81 in Ping Long, Hong Kong (Dudgeon 1986).

While we calculated the density of Melanoides from only four stovepipe samples collected in 2004 and measurements in 2006 were not statistically higher $(\mathrm{t}=-0.9976, \mathrm{df}=6, \mathrm{p}=$ 0.3570 ), overall trends suggest the population has continued to increase over the past few years. Giovanelli et al. (2005) found Melanoides populations capable of exponential growth to over 1,000 individuals $\mathrm{m}^{-2}$ just a few months after establishment, so it is reasonable to assume that the introduction of Melanoides did take place around 2001.

\section{Carbon cycling in Kelly Warm Springs}

Kelly Warm Springs was a highly productive yet net heterotrophic stream during summer 2006. The $500 \mathrm{~m}$ reach was supersaturated with $\mathrm{CO}_{2}$ with respect to atmospheric concentrations during the entire study period; and Kelly Warm Springs acted as a net source of $\mathrm{CO}_{2}$ throughout diel cycles and the summer months in general. Rates of primary production and respiration in Kelly Warm Springs were higher than most streams (Mulholland et al. 2001) as well as Polecat Creek, another highly productive stream in the greater Yellowstone ecosystem (Hall et al. 2003). Despite extremely high rates of productivity, Kelly Warm Springs was net heterotrophic during six of the seven 24-hour cycles we recorded changes in dissolved oxygen.

As with many freshwater ecosystems, Kelly Warm Springs was consistently supersaturated with respect to atmospheric $\mathrm{pCO}_{2}$. While some of this $\mathrm{CO}_{2}$ saturation can be attributed to a P:R (GPP:CR) of -0.85 , much of this $\mathrm{CO}_{2}$ likely comes from the upwelling of $\mathrm{CO}_{2}$-rich spring water above our study reach. This constant source of inorganic carbon, along with warm temperatures, may be important factors behind the high productivity in Kelly Warm Springs.

While methods have been developed to quantify inorganic carbon dynamics within aquatic ecosystems as well as evasion rates of $\mathrm{CO}_{2}$ into the atmosphere, it is still uncertain how much of this $\mathrm{CO}_{2}$ evasion is driven by biological versus physical and geological processes. We show here that photosynthesis and respiration, which alter $\mathrm{pH}$ in aquatic systems, can drive 24-hour cycles in $\mathrm{CO}_{2}$ concentrations and, consequently, $\mathrm{CO}_{2}$ evasion.

\section{Contributions of Melanoides to carbon cycling}

Melanoides calcification and $\mathrm{CO}_{2}$ production rates in Kelly Warm Springs were similar to rates calculated for other aquatic invertebrates, but were small in comparison to daily inorganic carbon fluxes driven by photosynthesis and respiration. However, the rate of $\mathrm{CO}_{2}$ production via shell synthesis was significant in comparison to daily net ecosystem production (NEP) of $\mathrm{CO}_{2}$. When considering the role of invasive snails in freshwater inorganic carbon cycling, the introduction and establishment of Melanoides in Kelly Warm Springs has increased net biological $\mathrm{CO}_{2}$ production and, consequently, $\mathrm{CO}_{2}$ evasion from the water into the atmosphere.

Beyond dominating the invertebrate organic carbon pool, the shell mass of Melanoides may be an important inorganic carbon reserve that could alter biogeochemical cycling. Melanoides have thick shells (and grow to a much larger size than any of the other mollusks present in Kelly Warm Springs) that will take several years to dissociate after death, especially in Kelly Warm Springs with high calcium $\left(\mathrm{Ca}^{2+}\right)$ concentrations 
and $\mathrm{pH}$, which impede $\mathrm{CO}_{2}$ dissolution (Strayer and Malcom 2007). Decreases in $\mathrm{CaCO}_{3}$ precipitation can also reverse this trend of $\mathrm{CO}_{2}$ production and act as a $\mathrm{CO}_{2}$ sink, especially during exoskeleton dissolution (Orr et al. 2005).

Melanoides $\mathrm{CO}_{2}$ production via biotic calcification was similar to other mollusks, including the invasive freshwater bivalves Dreissena polymorpha and Corbicula fluminea (Chauvaud et al. 2003). We calculated additional annual $\mathrm{CO}_{2}$ production estimates for several different marine calcifying organisms for further comparisons, most of which were in a similar range to Melanoides $\mathrm{CO}_{2}$ production after accounting for the difference in $\Psi$ between salt and freshwater systems (Table 1). If Melanoides consumed a larger proportion of primary producers in Kelly Warm Springs, it is possible that they would have more of an impact on ecosystem inorganic carbon cycling and $\mathrm{CO}_{2}$ fluxes (Schindler et al. 1997). On the other hand, it is unlikely that ecosystems could support higher densities and/or higher production rates of snails without a preceding increase in GPP.

$\mathrm{CO}_{2}$ production by Melanoides, while only a fraction of daily inorganic carbon cycling in relation to GPP and CR, was $13.6 \%$ of the net biological $\mathrm{CO}_{2}$ production in Kelly Warm Springs (Figure 6). Despite the large proportion of $\mathrm{CO}_{2}$ that was quickly transformed to $\mathrm{HCO}_{3}^{-}$within the carbonate pool, we estimated the potential impacts of losing calcifying Melanoides from Kelly Warm Springs. Compared to the total net $\mathrm{CO}_{2}$ production from biological processes (NEP + calcification), diffusion and reaeration were responsible for the evasion of $48.7 \%$ of the net biological $\mathrm{CO}_{2}$ production. Holding all other processes equal, the loss of calcifying Melanoides would decrease Kelly Warm Springs $\mathrm{CO}_{2}$ evasion rates from 37.2 to $32.1 \mathrm{mmol} \mathrm{CO}_{2} \mathrm{~m}^{-2}$ day $^{-1}$.

This study demonstrates the potential role of invasive species as a source of $\mathrm{CO}_{2}$ to stream inorganic carbon budgets as well as the ecosystemlevel impacts of an exotic snail. Melanoides can contribute substantially to total biological $\mathrm{CO}_{2}$ production through calcification, which must be calculated independently from stream metabolism. Biotic calcification did increase calculations of total $\mathrm{CO}_{2}$ production and evasion in Kelly Warm Springs. In freshwater systems that are already super-saturated with $\mathrm{CO}_{2}$, successful invasions by calcifying organisms may contribute to higher $\mathrm{CO}_{2}$ evasion rates. The escalating introduction and spread of invasive mollusks worldwide will have important consequences when considering the biological processes responsible for $\mathrm{CO}_{2}$ evasion from aquatic systems.

Table 1. Approximate $\mathrm{CO}_{2}$ production via calcification by several different freshwater and marine organisms. Freshwater organisms are noted with a "*" and calcification values calculated from other sources by Chauvaud et al. (2003) are noted with a "+””.

\begin{tabular}{|c|c|c|}
\hline Organism & $\begin{array}{l}\mathrm{CO}_{2} \\
\text { Production } \\
\text { (moles } \mathrm{CO}_{2} \\
\mathrm{~m}^{-2} \text { year }^{-1} \text { ) } \\
\end{array}$ & Citation \\
\hline $\begin{array}{l}\text { Dreissena } \\
\text { polymorpha* } \\
\text { (zebra mussels) }\end{array}$ & $0-18.0$ & $\begin{array}{l}\text { Chauvaud et } \\
\text { al. } 2003^{+}\end{array}$ \\
\hline $\begin{array}{l}\text { Heteropod } \\
\text { mollusks }\end{array}$ & $\begin{array}{l}4.7 \times 10^{-4}- \\
16.6 \times 10^{-4}\end{array}$ & Fabry 1990 \\
\hline $\begin{array}{l}\text { Pteropod } \\
\text { mollusks }\end{array}$ & $\begin{array}{l}3.3 \times 10^{-3}- \\
15.6 \times 10^{-3}\end{array}$ & Fabry 1990 \\
\hline Bryozoans & 0.4 & $\begin{array}{l}\text { Smith \& } \\
\text { Nelson } 1994\end{array}$ \\
\hline $\begin{array}{l}\text { Potamocorbula } \\
\text { amurensis } \\
\text { (Asian clam) }\end{array}$ & 1.8 & $\begin{array}{l}\text { Chauvaud et } \\
\text { al. } 2003\end{array}$ \\
\hline $\begin{array}{l}\text { Corbicula } \\
\text { fluminea* } \\
\text { (freshwater } \\
\text { Asian clam) }\end{array}$ & $1.8-10.8$ & $\begin{array}{l}\text { Chauvaud et } \\
\text { al. } 2003^{+}\end{array}$ \\
\hline $\begin{array}{l}\text { Bryozoans, } \\
\text { coralline algae, } \\
\text { echinoderms and } \\
\text { mollusks }\end{array}$ & 2.4 & Smith 1972 \\
\hline $\begin{array}{l}\text { Seagrass } \\
\text { epiphytes }\end{array}$ & 3.2 & $\begin{array}{l}\text { Chauvaud et } \\
\text { al. } 2003^{+}\end{array}$ \\
\hline $\begin{array}{l}\text { Crepidula } \\
\text { fornicata } \\
\text { (slipper limpet) }\end{array}$ & 3.6 & $\begin{array}{l}\text { Martin et al. } \\
2006\end{array}$ \\
\hline $\begin{array}{l}\text { Melanoides } \\
\text { tuberculata* } \\
\text { (red-rim } \\
\text { melania) }\end{array}$ & 3.8 & This study \\
\hline $\begin{array}{l}\text { Ophiothrix } \\
\text { fragilis (brittle } \\
\text { star) }\end{array}$ & 4.8 & $\begin{array}{l}\text { Migné et al. } \\
1998\end{array}$ \\
\hline Coral reef systems & 6.0 & $\begin{array}{l}\text { Gattuso et al. } \\
1998\end{array}$ \\
\hline $\begin{array}{l}\text { Crustose coralline } \\
\text { algae }\end{array}$ & $9.7-66.9$ & $\begin{array}{l}\text { Chisholm } \\
2000\end{array}$ \\
\hline Foraminifera & 12.0 & $\begin{array}{l}\text { Chauvaud et } \\
\text { al. } 2003^{+}\end{array}$ \\
\hline
\end{tabular}




\section{$\downarrow$ ACKNOWLEDGMENTS}

We would like to acknowledge E.G. Pendall, A.C. Krist and L.A. Kunza for their helpful comments and discussions on earlier versions of this manuscript. Without logistical support from S. O’Ney (NPS) and H. Harlow (UW-NPS Research Station), this project would not have been possible. We would like to acknowledge field and laboratory assistance from R. Crosby, J. Theurer, N. Swoboda-Colberg, T. Lehnertz, C. Boese, M. Vaughn and K. Hogeland. Discussions with J.S. Meyer and L. Riley also contributed greatly to the success of this project. This research was funded by a UW-NPS research grant awarded to R.O. Hall and E.R. Hotchkiss. Work for this project was also supported by a University-Wide Plummer Scholarship (School of Environment and Natural Resources, University of Wyoming), a Dennis Jesperson Memorial Scholarship (Wyoming Wildlife Fund), and a Colorado Lake and Reservoir Management Association Scholarship. This manuscript is a contribution to the University of Wyoming/National Park Service Research Station.

\section{$\downarrow \quad$ Literature Cited}

Benke, A.C. 1984. Secondary production of aquatic insects. Pages 289-322 in Ecology of aquatic insects. V. H. Resh and D. M. Rosenberg, eds. Praeger Publishers, New York.

Berry, A.J. and A.B.H. Kadri. 1974. Reproduction in the Malayan freshwater cerithiacean gastropod Melanoides tuberculata. Journal of Zoology, London 172: 369381 .

Cai, W.-J. and Y. Wang. 1998. The chemistry, fluxes, and source of carbon dioxide in the estuarine waters of the Satilla and Altamaha Rivers, Georgia. Limnology \& Oceanography 43: 657-668.

Chauvaud, L., J.K. Thompson, J.E. Cloern and G. Thouzeau. 2003. Clams as $\mathrm{CO}_{2}$ generators: The Potamocorbula amurensis example in San Francisco Bay. Limnology \& Oceanography 48: 20862092.
Chisholm, J.R.M. 2000. Calcification by crustose coralline algae on the northern Great Barrier Reef, Australia. Limnology \& Oceanography 45: 1476-1484.

Cole, J.J., N.F. Caraco, G.W. Kling and T.K. Kratz. 1994. Carbon dioxide supersaturation in the surface waters of lakes. Science 265: 1568-1570.

Cole, J.J. and N.F. Caraco. 1998. Atmospheric exchange of carbon dioxide in a low wind oligotrophic lake measured by the addition of $\mathrm{SF}_{6}$. Limnology \& Oceanography 43: 647-656.

Cole, J.J., M.L. Pace, S.R. Carpenter and J.F. Kitchell. 2000. Persistence of net heterotrophy in lakes during nutrient additions and food web manipulations. Limnology \& Oceanography 45: 17181730.

Cole, J.J., Y.T. Prairie, N.F. Caraco, W.H. McDowell, L.J. Tranvik, R.G. Striegl, C.M. Duarte, P. Kortelainen, J.A. Downing, J.J. Middleburg and J. Melack. 2007. Plumbing the global carbon cycle: Integrating inland waters into the terrestrial carbon budget. Ecosystems 10: 171-184.

Duarte, C.M. and Y.T. Prairie. 2005. Prevalence of heterotrophy and atmospheric $\mathrm{CO}_{2}$ emissions from aquatic ecosystems. Ecosystems 8: 862-870.

Dudgeon, D. 1986. The life cycle, population dynamics and productivity of Melanoides tuberculata (Müller, 1774) (Gastropoda: Prosobranchia: Thiaridae) in Hong Kong. Journal of Zoology, London 208: 37-53.

Duggan, I.C. 2002. First record of a wild population of the tropical snail Melanoides tuberculata in New Zealand natural waters. New Zealand Journal of Marine and Freshwater Research 36: 825829. 
Fabry, V.F. 1990. Shell growth rates of pteropod and heteropod molluscs and aragonite production in the open ocean: Implications for the marine carbonate system. Journal of Marine Research 48: 209-222.

Facon, B., J.-P. Pointer, M. Glaubrecht, C. Poix, P. Jarne and P. David. 2003. A molecular phylogeography approach to biological invasions of the New World by parthenogenetic Thiarid snails. Molecular Ecology 12: 3027-3039.

Facon, B., B.J. Genton, J. Shykoff, P. Jarne, A. Estoup and P. David. 2006. A general eco evolutionary framework for understanding bioinvasions. Trends in Ecology \& Evolution 21: 130-135.

Frankignoulle, M., C. Canon and J.-P. Gattuso 1994. Marine calcification as a source of carbon dioxide: Positive feedback of increasing atmospheric $\mathrm{CO}_{2}$. Limnology \& Oceanography 39: 458-462.

Gattuso, J.-P., M. Frankignoulle, I. Bourge, S. Romaine and R.W. Buddemeier. 1998. Effect of calcium carbonate saturation of seawater on coral calcification. Global and Planetary Change 18: 37-46.

Giovanelli, A., M. V. Vieira and C.L.P.A Coelho da Silva. 2003. Apparent competition through facilitation between Melanoides tuberculata and Biomphalaria glabrata and the control of schistosomiasis. Memórias do Instituto Oswaldo Cruz 98: 429-431.

Giovanelli, A., M.V. Vieira and C.L.P.A. Coelho da Silva. 2005. Interaction between the intermediate host of Schistosomiasis in Brazil, Biomphalaria glabrata (Say, 1818) and a possible competitor, Melanoides tuberculata (Müller, 1774): A field study. Journal of Molluscan Studies 71: 7-13.

Hall, R.O., J.L. Tank and M.F. Dybdahl. 2003. Exotic snails dominate nitrogen and carbon cycling in a highly productive stream. Frontiers in Ecology and Environment 1: 407-411.
Hall, R.O., M.F. Dybdahl and M.C. VanderLoop. 2006. Extremely high secondary production of introduced snails in rivers. Ecological Applications 16: 1121-1131.

Hall. R.O., S. Thomas and E.E. Gaiser. 2007. Measuring primary production and respiration in freshwater ecosystems. Pages 175-203 in Principles and Standards for Measuring Primary Production. T.J. Fahey and A.K. Knapp, eds. Oxford University Press, Oxford.

Jacob, J. 1957. Cytological studies of Melaniidae (Mollusca) with special reference to parthenogenesis and polyploidy. I. Oogenesis of the parthenogenetic species of Melanoides (ProsobranchiaGastropoda). Transactions of the Royal Society of Edinburgh. 63: 341-352.

Jones, J.B., E.H. Stanley, and P.J. Mulholland. 2003. Long-term decline in carbon dioxide supersaturation in rivers across the contiguous United States. Geophysical Research Letters 30:10.1029/2003GL017056.

Kiibus, M. and N. Kautsky. 1996. Respiration, nutrient excretion and filtration rate of tropical freshwater mussels and their contribution to production and energy flow in Lake Kariba, Zimbabwe. Hydrobiologia 331: 25-32.

Langmuir, D. 1997. Aqueous Environmental Chemistry. Prentice Hall, Upper Saddle River, New Jersey.

Livshits, G. and L. Fishelson. 1983. Biology and reproduction of the freshwater snail Melanoides tuberculata (Gastropoda: Prosobranchia) in Israel. Israel Journal of Zoology. 32: 21-35.

Love, J.D. and J.M. Love. 1988. Geological road log of part of the Gros Ventre River valley including the lower Gros Ventre slide. Geological Survey of Wyoming: Laramie, WY. 
Martin, S., G. Thouzeau, L. Chauvaud, F. Jean, L. Guérin and J. Clavier. 2006. Respiration, calcification, and excretion of the invasive slipper limpet, Crepidula fornicata L: Implications for carbon, carbonate, and nitrogen fluxes in affected areas. Limnology \& Oceanography 51: 1996-2007.

Migné, A., D. Davoult and J.-P. Gattuso. 1998. Calcium carbonate production of a dense population of the brittle star Ophiothrix fragulis (Echinodermata: Ophiuroidea): role in the carbon cycle of a temperate coastal ecosystem. Marine Ecology Progress Series 173: 305-308.

Millero, F.J. 1979. The thermodynamics of the carbonate system in seawater. Geochimica et Cosmochimica Acta 43: 1651-1661.

Mulholland, P.J., C.S. Fellows, J.L. Tank, N.B. Grimm, J.R. Webster, S.K. Hamilton, E. Martí, L. Ashkenas, W.B. Bowden, W.K. Dodds, W.H. McDowell, M.J. Paul and B.J. Peterson. 2001. Inter-biome comparison of factors controlling stream metabolism. Freshwater Biology 46: 1503-1517.

Odum, H.T. 1956. Primary production in flowing waters. Limnology \& Oceanography 1: 102-117.

Orr, J.C., V.J. Fabry, O. Aumont, L. Bopp, S.C. Doney, R.A. Feely, A. Gnanadesikan, N. Gruber, A. Ishida, F. Joos, R.M. Key, K. Lindsay, E. Maier-Reimer, R. Matear, P. Monfray, A. Mouchet, R.G. Najjar, G.-K. Plattner, K.B. Rodgers, C.L Sabine, J.L. Sarmiento, R. Schlitzer, R.D. Slater, I.J. Totterdell, M.-F. Weirig, Y. Yamanaka and A. Yool. 2005. Anthropogenic ocean acidification over the twenty-first century and its impact on calcifying organisms. Nature 437: 681-686.

Pointier, J.-P., B. Delay, J.L. Toffart, M. Lefèvre and R. Romero-Alvarez. 1992. Life history traits of three morphs of Melanoides tuberculata (Gastropoda: Thiaridae), an invading snail in the French West Indies. Journal of Molluscan Studies 58: 415-423.
Pointier, J.-P. and M. Giboda. 1999. The case for biological control of snail intermediate hosts of Schistosoma mansoni. Parasitology Today 15: 395-397.

Portielje, R. and L. Lijklema. 1995. Carbon dioxide fluxes across the air-water interface and its impact on carbon availability in aquatic systems. Limnology \& Oceanography 40: 690-699.

Rader, R.B., M.C. Belk and M.J. Keleher. 2003. The introduction of an invasive snail (Melanoides tuberculata) to spring ecosystems of the Bonneville Basin, Utah. Journal of Freshwater Ecology 18: 647-657.

Raine, R.C.T. 1983. The effect of nitrogen supply on the photosynthetic quotient of natural phytoplankton assemblages. Botanica Marina 26: 417-423.

Richey, J.E., J.M. Melack, A.K. Aufdenkampe, M.V. Ballester and L.L. Hess. 2002. Outgassing from Amazonian rivers and wetlands as a large tropical source of atmospheric $\mathrm{CO}_{2}$. Nature 416: 617-620.

Robinson, D.G. 1999. Alien Invasions: The effects of the global economy on non marine gastropod introductions into the United States. Malacologia 41: 413-438.

SAS Institute. 2002-2003. SAS/STAT User's Guide, Release 9.1.3. Cary, North Carolina.

Simon, K.S. and C.R. Townsend. 2003. Impacts of freshwater invaders at different levels of ecological organisation, with emphasis on salmonids and ecosystem consequences. Freshwater Biology 48: 982-994.

Smith, S.V. 1972. Production of calcium carbonate on the mainland shelf of southern California. Limnology \& Oceanography 17: 28-41.

Smith, A.M. and C.S. Nelson. 1994. Calcification rates of rapidly colonizing bryozoans in Hauraki Gulf, northern New Zealand. New Zealand Journal of Marine and Freshwater Research 28: 227-234. 
Strayer, D.L. and H.M. Malcom. 2007. Shell decay rates of native and alien freshwater bivalves and implications for habitat engineering. Freshwater Biology 52: 1611-1617.

Subba Rao, N.V. and S.C. Mitra. 1982. Bioecology of two melaniid snails (Mollusca: Gastropoda) in ponds near Calcutta. Journal of the Zoological Society of India 1\&2: 21-32.

Tans, P. 2007. Global monthly mean $\mathrm{CO}_{2}$ data. NOAA/ESRL.

www.esrl.noaa.gov/gmd/cgg/trends

U.S. Geological Survey. 2005. Nonindigenous Aquatic Species Database, Gainesville, FL. http://nas.er.usgs.gov.

Vanni, M.J. 2002. Nutrient cycling by animals in freshwater ecosystems. Annual Review of Ecology and Systematics 33: 341-370.

Wanninkhof, R., P.J. Mulholland and J.W. Elwood 1990. Gas exchange rates for a first order stream determined with deliberate and natural tracers. Water Resources Research 26: 1621-1630.
Wanninkhof, R. 1992. Relationship between wind speed and gas exchange over the ocean. Journal of Geophysical Research 97: 7373-7382.

Wanninkhof, R. and M. Knox. 1996. Chemical enhancement of $\mathrm{CO}_{2}$ exchange in natural waters. Limnology \& Oceanography 41 : 689-697.

Ware, J.R., S.V. Smith and M.L. Reaka-Kudla. 1991. Coral reefs: sources or sinks of atmospheric $\mathrm{CO}_{2}$ ? Coral Reefs 11: 127130.

Wetzel, R.G. and G.E. Likens. 2000. Limnological Analyses. 3rd edition. Springer Verlag, New York.

Wetzel, R.G. 2001. Limnology. 3rd edition. Academic Press, San Diego, CA. 